\title{
STIMULASI TUMBUH KEMBANG ANAK
}

\author{
Sri Yenawati \\ Fakultas Psikologi UIN Sunan Gunung Djati Bandung \\ Jl. Raya Cipadung No. 105 Bandung 10614 Telp (022) 7800525 email: yenapalem@yahoo.com
}

Children, like adults are also have their own problems in life. Nowadays, we also know that lacks of self confidence not just for adult only, children are also have the same problem. It is also encouraged by their undeveloped ability both mentally and physically. Independency is also one of many problems that must be faced by children especially children with mental disorder or mental retardation. This phenomena then become a basis for this research - that is emphasizes on children development stimulation. It was also considered that pre-natal condition is also has influence over children's development after they born. This paper is then pre-describe developmental stage of children at their golden age, with developmental tasks and crisis that come along within every stages. Stimulation to encourage children's development would also be discussed in this paper with hopes that many people could then take any profit from this paper and optimizing their effort in raising and teaching their children.

Keyword: child development, babyhood, childhood

\section{Pendahuluan}

Dilatarbelakangi permasalahan anak yang banyak terjadi pada saat ini seperti banyaknya anak yang kurang percaya diri, kemandirian pada masa sekolah belum terbentuk juga cenderung banyak anak berkebutuhan khusus, penulis tertarik untuk membahas stimulasi tumbuh kembang anak karena beranggapan bahwa apa yang terjadi sebelum kelahiran dapat memahami pemahaman tentang apa yang terjadi sesudah lahir, begitu pula apa yang terjadi lima tahun awal kehidupan anak (Golden Age) yang penting bagi pembentukan kepribadian anak dikemudian hari. Menurut Hurlock (1978) Periode Pralahir dianggap sebagai periode yang sangat penting. Menurut periode Pranatal/Pralahir ini mempunyai karakteristik penting seperti: 1) Pembawaan lahir: Secara fisik (seperti warna mata dan bentuk kulit, rambut), maupun mental (Intelegensi, sifat genetik, penyakit) dan segala hal pembawaan yang berfungsi untuk perkembangan selanjutnya ditentukan saat ini; 2) Pertumbuhan dan perkembangan yang cepat: Diperkirakan selama kehamilan 9 bulan perkembangan meningkat $90 \%$, selain itu seluruh organ dan ciri tubuh manusia sedang dibentuk, apalagi 3 bulan pertama dimana organ-organ penting sedang terbentuk seperti otak, jantung, hati dan fungsi organ penting lain. Sehingga ibu hamil pada masa ini sebaiknya cukup asupan gizinya, karena akan mempengaruhi perkembangan intelektual, motorik dan bahasa anak di kemudian hari; 3) Kondisi dalam lingkungan pralahir: Kondisi tubuh ibu (seperti kondisi fisik dan emosional) yang menguntungkan mempertinggi perkembangan potensi bawaan, sedangkan kondisi yang buruk dapat menghalangi atau mengganggu pola perkembangan selanjutnya. 
Kondisi yang dapat ditentukan pada saat pembuahan seperti: penentuan jenis kelamin, jumlah anak (tunggal/kembar) dan urutan dalam keluarga (pandangan urutan kelahiran dan peran yang diharapkan) menentukan dan mempunyai pengaruh terhadap prilaku dan kepribadian anak di sepanjang hidupnya; 4) Sikap orang-orang yang berarti: Sikap orang tua terhadap anaknya dipengaruhi oleh konsep mereka terhadap peran menjadi orang tua) dan sikap anggota keluarga yang terbentuk pada waktu itu mempunyai pengaruh yang nyata terhadap perlakuannya pada anak pada tahun awal pembentukan kehidupan.

Begitu juga dengan pemahaman masa anak setelah lahir sangat penting terutama bagi pelaksanaan stimulasi tumbuh kembangnya, hal ini dapat mengajak kita untuk mengenal dan memahami tugas-tugas perkembangan dan krisis terjadi selama perkembangan anak sehingga kita dapat mengetahui apa yang dapat diharapkan berkembang dan kapan pencapaiannya, dapat merangsang pertumbuhannya atau tidak, hingga dapat merencanakan pemberian dorongan pada saat yang tepat dan memungkinkan kita untuk mempersiapkan dirinya untuk menjalani perubahan dan penyimpangan yang akan terjadi. Setiap individu mempunyai kecepatan yang berbeda tergantung dari kematangan dan proses belajar.

\section{Pembahasan}

Bila melihat dari segi usianya menurut Hurlock (1978) masa kini dibagi dalam empat periode: 1) Usia 0-2/3 tahun disebut masa perkembangan bayi; 2) Usia 2-6 tahun masa anak-anak awal (Early Chilhood); 3) Usia 612/13 tahun masa pertengahan dan akhir anak (late childhood); 4) Usia 12-15 tahun masa remaja awal (Pubertas).

Masa bayi; (berlangsung dari usia 0-2/3). Biasanya diistilahkan sebagai BATITA (di bawah tiga tahun) terdapat: a) Masa Infancy (merupakan periode tersingkat dalam kehidupan) lamanya berlangsung dari saat lahir sampai tanggalnya tali pusar (periode partinate), dilanjutkan dengan penyesuain diri terhadap lingkungan di luar kandungan (periode neonate), sehingga disebut sebagai periode penyesuaian diri. Diharapkan bayi dapat menghadapi keadaan lingkungan yang baru (dari dalam kandungan/parasit setelah lahir menjadi independent) hingga berat badannya menurun berlangsung kira-kira 1 minggu kemudian bertambah setelah terjadi penyesuaian yang baru (terhadap temperatur, dalam bernafas dan dalam menghisap/menelan), perkembangannya seakan plateau/tidak ada kemajuan. Banyak dipengaruhi lingkungan prenatal (sikap orang tua, perawatan semasa hamil), proses kelahira da asupan gizi. Penting diperhatikan pada masa ini adalah perkembangan gerakan refleks (gerakan bayi yang bersifat otomatis dan tidak terkoordinir sebagai reaksi terhadap rangsangan tertentu serta memberi bayi respon penyesuain diri terhadap lingkungannya) seperti refleks moro (respon tiba-tiba dari bayi lahir akibat adanya suara atau gerakan yang mengejutkan) sebagai upaya mempertahankan hidupnya. Refleks ini sangat penting dapat mendiagnosa perkembangan sisitem saraf normal bayi; b) Masa Babyhood, berlangsung 
sampai anak berusia dua tahun pertama dari kelahiran, masa ini disebut sebagai periode vital karena kondisi fisik dan psikologis bayi pada masa ini merupakan pondasi yang kokoh bagi perkembangan dan pertumbuhan selanjutnya (basic age, dasar peletakan, sikap mental terhadap orang lain atau dirinya sendiri ditentukan pada masa ini ditentukan pada masa ini), merupakan periode perkembangan yang tercepat/ terjadi tidak hanya perubahan tidak hanya fisik/penampilan tetapi kemauan juga (gerakan bayi lebih terkoordinir dan dalam kemampuan sosial lebih responsif). Banyak dipengaruhi oleh kematangan dan proses belajar melalui proses akomodasi (cara menyesuaikan diri dengan keadaan diluar) dan proses asimilasi (belajar membedakan antara benda yang bias dihisap atau tidak, berusaha menyesuaika kebutuhan dengan keadaan diluar) walaupun masih ada ketergantungan, hingga tugas perkembangan yang diharapkan dikuasai pada masa ini), merupakan periode perkembangan yang tercepat/terjadi perubahan tidak hanya fisik/penampilan tetapi kemampuan juga (gerakan bayi lebih tekordinir dan dalam kemampuan sosial nampak lebih responsif) banyak dipengaruhi oleh kematangan dan proses belajar melalui proses akomodasi (cara menyesuaikan dirinya dengan kedaan diluar) dan proses asimilasi (belajar membedakan antara beberapa benda yang dapat diisap atau tidak, berusaha menyesuaiakan kebutuhan dengan keadaan diluar) walaupun masih ada ketergantungan, hingga tugas perkembangan yang diharapkan dapat dikuasai pada masa ini belajar memakan makanan padat, berjalan, mengontrol organ pembuangan, belajar bicara dan mengadakan hubungan emosional dengan orang tua dan saudaranya.

Pada tahap ini, zone/ wilayah aktivitasnya adalah mulut, muncul reflex menghisap (mulut sebagai suatu cara untuk mempelajari objek-objek baru), yang memiliki mode aktivitas “incorporation" (penggabungan), yang meliputi alat-alat indra yang lain (Erikson: 1985). Contoh: selain menerima sesuatu melalui mulut, seorang bayi juga melihat sesuatu yang menarik melalui matanya, selanjutnya dengan perabaan akan terjadi gerak reflex menggenggam ketika objek diraba dan secara otomatis jari tangannya menutup secara melingkar. Jadi penggabungan ini menggambarkan awal mula ego bayi berhubungan dengan dunia eksternal. Dengan kematangan, bayi dapat secara aktif mengulurkan tangannya dan menggenggam benda dengan tangannya. Demikian pula mata, dimana pada awalnya relatif pasif dalam menerima kesan-kesan, dan seterusnya belajar untuk memfokuskan dan menangkap objek dari latar belakang yang kabur. Pada ahirnya diikuti oleh aktivitas pendengaran.

Krisis yang terjadi pada tahap ini adalah tahap basic trust vs mistrust. Cara mengatasi krisis pada masa ini,penting diperhatikan asupan gizi dan inteersksi bayi dengan orang terdekat disekitar kehidupannya terutama ibu, Bayi menemukan suatu kemantapan (ketetapan), suatu yang dapat diramalkan dan sesuatu yang dapat dipercaya dari tindakan pengasuhnya, misalnya bila orang tua datang dengan cepat dan meladeni bayi secara ikhlas dan 
penuh kehangatan (saat kedinginan, ngompol atau lapar), maka bayi belajar bahwa orangtuanya dapat dipercaya dan mantap. Hal ini akan membant anak dalam mengembangkan rasa trust, sebaliknya bila bayi merasa orang tuanya kurang dapat dipercaya, maka ia akan mengembangkan mistrust.

Contoh lain jika anak akan makan, cara pemberian makan seringkali frustrasi dan selanjutnya bayi akan menuju mistrust. Begitu juga jika kausalitas hubungan kasih sayang yang buruk serta ibu menolak secara emosional sementara bayi dipenuhi kebutuhan fisiknya saja, maka rasa trust akan rusak.

Saat tumbuh gigi merupakan masa belajar percaya terhadap dirinya sendiri, dan mengatur dorongannya untuk mengisap tanpa menggigit serta mengggenggam tanpa melukai. Pada masa ini, seorang ibu sebaiknya hati-hati, jangan menarik diri atau menyapih dengan tiba-tiba.

Tanda percaya muncul ketika bayi mau dibiarkan oleh ibu tanpa keluh kesah, dapat mentolelir lebih baik ketidakhadiran ibu, dan tidak memerlukan perhatian dengan segera. Bayi dapat menahan kebutuhannya yang memuncak karena dia telah belajar bahwa ibunya akan datang pada waktu yang seharusnya. Kerusakan pada rasa trust yang terjadi dalam hubungannya antara bayi dan ibu dapat diperbaiki pada tahun-tahun selanjutnya. Trust tergantung pada penanaman kepercayaan yang baik dari orang tuanya atau pengganti ibu, dimana mereka harus dapat memperlihatkan hal ini lebih dalam pada anak dan meanamkan suatu pendirian bahwa ada suatu arti dalam asuhan yang mereka lakukan (percaya terhadap diri sendiri). Pada awal kehidupan bayi mempunyai empati fisik khusus terhadap figur ibu, dimana bayi secaara otomatis dapat merasakan ketegangan ibunya. Karena bayi memerlukan sentuhan, maka orang tua dianjurkan mengikuti gerak hatinya untuk bereaksi pada kebuthan-kebutuhan bayinya. Orang tua juga dainjurkan memiliki inner assurance (ketenangan jiwa) dan inner security (rasa aman) yang di peroleh dari agama dan selanjutnya akan diteruskan pada anaknya, ehingga memberi sentuhan pada anak bahwa dunia adalah tempat yang dapat dipercaya (Sullivan: 1985).

Masa anak; (berlangsung dari usia 212/13 tahun) dibagi dalam dua periode: a) Masa anak awal (mulai usia 2/3-6 tahun), biasanya diistilahkan dengan masa BALITA, yang membedakan masa anak dengan masa bayi adalah: penggunaaan bahasa dan kesadaran akan diri (anak punya pilihan apa yang disukai dan yang tidak disukai, mulai menolak koreksi dari orang tua). Hingga disebut juga problem age (mulai menyusahkan orang tua), pada masa ini mempunyai kelebihan energi/ banyak gerak, perkembangan motorik/fisik perlu penyaluran, perlu tempat bermain masuk PG/TK hingga disebut juga usia pra-sekolah usia explore/try age, mulai mengadakan penjelajahan (banyak bertanya apa, mengapa dan bagaimana? (questioning age) usia peka terhadap rangsangan intelektual. Anak menunjukkan kreatifitas yang lebih besar, karena adanya perkembangan imajinasi, bersandiwara peran dokter-dokteran,warung-warungan/jualan, perkembangan bahasa meningkat. Mulai menge- 
nal identitas sebagai laki-laki/perempuan (sex typing), saat main berkelompok (pre-gang age) peniruan ini ahirnya akan muncul mengambil peranan sesuai dengan jenis kelaminnya (imitative age). belajar control toilet training, berusaha untuk bisa mengendalikan impulsimpuls syaraf/ blender kontrol (11/2 tahun BAK sudah dilath, 5 tahun bisa mandi dan BAB sendiri). Belajar mengembangkan sistim pengendalian terhadap keinginan, menyatakan/ menahan kemauannya, belajar sopan santun (belajar moral dan sistim nilai). Belajar pisah dengan ibu (agar tidak terjadi dependency emosional) jadi pada masa ini ditandai oleh ketidak terrgantungan dan berahir dengan kematangan.

Pada tahap ini awalnya zone yang diminati anak (muncul anatara usia 1,5 s.d. 3 tahun). Dipengaruhi oleh kematangan pada system saraf, dimana anak memperoleh kontrol pada sphinternya, dapat menahan dan mengeluarkan apa yang mereka kehendaki, terutama isi perutnya dan kandung kemihnya.

Konflik atau krisis pada tahap ini adalah autonomi vs shame and doubt. Pada tahap ini, anak mencoba latihan memilih, mereka menggunakan kemauannya atau rasa otonominya jika menghendaki mereka ingin dipeluk, dan jika tidak mereka akan menolak (dienyahkan), kematangan ini mengantarkan bayi pada kemampuan untuk maengeluarkan atau mempertahankan materi yang dibuang dari tubuhnya seperti mengosongkan isi perut atau kandung kemih yang dapat memberinya suatu perasaan berkuasa yang tumbuh dari kontrol terhadap sistem pengosongan tersebut. Hal ini merupa- kan dasar untuk mengembangkan otonominya dan dapat melakukan segala hal bagi dirinya sendiri (kemandirian). Merka juga menuntut makan sendiri, dan hanya memakai bahasa sendiri yang hanya dimengerti oleh dirinya sendiri serta mengexpresikan otonominya dalam kata tunggal "tidak". Usia 2 tahun, nampaknya nampaknya tidak sanggup mengatakan "ya" dimana artinya secara keseluruhan menghilangkan kebebasannya. Dengan kekerasan dan terus menerus mengatakan tidak, anak coba menentang seluruh control external.

Anak lebih banyak mengontrol diri mereka sendiri dan lebih banyak mengontrol ketidaksengajaan masyarakat juga cara orang tuanya mengajar merka bagaimana cara berkelakuan yang benar.anak mungkin menolak "toilet training", karena orang tua sering membuat mereka merasa malu, kotor dan tidak pantas hingga anak mungkin menolak melakukan hal itu. Padahal selama periode ini anak memerlukan sutu keseimbangan antara ketegasan, flexibilitas dan kesabaran orang tua, dalam membiarkan secara bertahap mengontrol pengeluaran kandung kemihnya. Jika pengontrolan diluar terlalu kuat atau terlalu awal, maka anak akan tidak berdaya untuk mengatur isi perutnya dan tidak berkuasa untuk mengontrol tindakan-tindakan orang tuanya sehingga ia akan mencari pemuasan dengan melakukan proses oral. Pemaksaan bowel training akan berpengaruh pada masa dewasanya. Dimana anak akan menjadi seorang yang over komplusif, kikir dan sangat teliti dengan cinta, tenaga, waktu dan uangnya. Tingkah 
laku over komplusif ini disertai perasaan ragu dan malu yang berlangsung lama.

Rasa otonomi datang dari dalam melalui kematangan biologis yang membantu membantu mengembangkan kemampuan untuk melakukan segala sesuatu oleh sendiri rasa malu atau sangsi datang dari kesadaran terhadap harapan dan dukungan sosial. Persaaan malu tersebut timbul ketika merasa tidak baik dimata orang lain. Sedangkan sangsi dari realisai bahwa seseorang sudah tidak mampu lagi melakukan tindakan yang baik.

Pada tahap ini kadang anak melakukan penundaan buang air besar (mengalami encopresis) untuk mendapatkan kepuasan pada saat pelepasannya. Beberapa orang tua membiarkannya, tetapi beberapa orangtua juga melakukan toilet training terhadapnya.

Beberapa anak menunjukan pemberontakan pada aturan ini, pada saat awal dewasa menunjukan karakter anal impulsive.

Marah dan takut yang ditimbulkan oleh toilet training diguankan untuk mengukur fiksasi. Akibatnya kebanyakan orang memiliki kecendrungan pada anal impulsive dan anal konpulsive atau kombinasi antara keduanya.

Cara mengatasinya: Latihan $\mathrm{BAB}(\mathrm{Bu}-$ ang Air Besar) dan BAk (Buang Air Kecil) secara bertahap yang dilakukan dengan dengan baik, dapat mem-bantu anak mengembangkan perasaan self control (control diri) tanpa kehilangan self esteem (harga diri) dan menjadikannya sebagai seorang dewasa dengan perasaan autonomi/ mandiri yang kuat tapi diterima secara sosial.
Anak dapat belajar menyesuaikan diri terhadap peraturan sosial tanpa merasa kehilangan rasa otonominya. Orang tua dapat membantunya dengan cara lemah lembut dan membantu anak mempelajari tingkah laku social tanpa menghancurkan kemauannya.

Tahap selanjutnya (Genital) berlangsung antara usia 3 sampai 6 tahun. Kelancaran pencapaian zona genital ini dipengaruhi oleh zona anal.Pada fase ini anak lebih memusatkan minatnya pada genital dan organ jenis kelamin lainnya.

Anak memasuki krisis odipal, dimana kata hati berkembang dan berfungsi sebagai suatu kontrol terhadap inisiatif.

Mode utamanya adalah intrusion pada masa ini anak sangat berani, selalu ingin tahu dan bersaing.

Konflik atau krisis yang terjadi pada masa ini intiative (inisitif) vs guilt (rasa bersalah). Anak mengartikan inisiatif dengan membawa rencana, menetapkan suatu tujuan dan mempertahankan pencapaiannya. Selama tahun ke 4 anak mencapai banyak keterampilan dalam mengggunakan bahasa, dan gerakan dan dalam menyelesaikan suatu masalah.

Imajinasinya berkembang mencakup banyak hal yang tidak dapat dihindari dan dipikirkannya sendiri. Hingga muncul istilah unbroken initiative, sebagai suatu dasar dari rasa ambisi dan kebebasan yang tinggi dan tidak realistik. Terutama ambisi dalam memiliki salah satu orang tuanya, dimana anak menemukan bahwa harapan ini melanggar secara mendalam tabu sosial. Sebagai akibatnya anak menginternalisasikan larangan sosial dan 
super egonya menghasilkan rasa bersalah, menangkap impuls yang berbahaya dan memilih melamun. Akibatnya terbentuk self restriction, sehingga secara individual terbentuk self funishment.

Dalam menghindari krisis oedipalnya, anak melakukan internalisasi super ego, yaitu degan memasukan nilai-nilai orang tuanya dan membentuk pengendalian internal untuk mengawasi impuls yang membahayakan. Super ego dapat daikatakan sebagai kata hati, yaitu yang menimbulkan rasa bersalah pada suatu hal buruk yang dilakukan, dimana sebelumnya anak selalu mendapatkan kritik dan hukuman, sekarang ia telah mampu mengkritik dirinya sendiri. Meskipun anak telah mencapai periode laten, tetapi perasaan oedipalnya masih bergerak dalam unconcious, dimana pada suatu waktu dapat muncul pada conscious.

Cara mengatasinya: Hal ini dapat dirubah dengan banuan orangtua. Caranya dengan mempermudah otoritasnya dan membolehkan anak berpartisipasi dengan mereka untuk bersama tertarik pada suatu proyek.

Masa pertengahan dan akhir anak; (berlangsung dari usia 6-12/13 tahun) dimulai dengan masuknya anak kesekolah dasar dan diahiri dengan masuknya masa remaja yang ditandai dengan kematangan secara sexual. Pada masa ini disebut usia sekolah dasar, anak diharapkan mengembangkan keterampilan dasar dalam membaca, menulis dan berhitung juga, belajar mengembangkan/mengorganisasikan pengetahun relitasa, fsik dan sosial, belajar bekerjasama dengan baik dalam kelompok teman sebaya (diistilahkan usia gang).
Belajar berperan sesuai dengan jenis kelamin (berperan sexual identity yang tepat) menjadi individu yang mandiri, disini terjadi proses penting yaitu identifikasi konsep dan peran sesuai jenis kelamin terhadap figur otoritas. Pada masa ini disebut latency, dorongan sexual dan agresif untuk sementara berhenti. Tahap ini paling menentukan untuk pertumbuhan ego, untuk itu penting bagi anak menguasai kognitif dan keterampilan social.

Konflik atau krisis pada tahap ini adalah industry $v$ s inferiority anak ini merupakan harapan yang selalu dimainkan didalam keluarganya, belajar menggunakan alat dan keterampilan yang bermanfaat. Anak mulai pergi ke sekolah dengan harapan dapat lebih menguasai kecakapan otaknya, dapat membaca, menulis dan berhitung. Di lain pihak mereka juga belajar dan bekerja dengan teman sebaya.

Jika orang dewasa memberi tugas-tugas yang dikenal dan menarik serta dilengkapi dengan pedoman-pedoman yang diperlukan, maka anak mempunyai kesempatan yang baik untuk melalui periode ini dengan rasa industry (giat, tekun).

Jika keluarga belum mempersiapkannya untuk bersekolah, maka periode ini akan menghasilkan perasaan in adequate (tidak sesuai) dan perasaan in priority (rendah diri) atau perasaan bersalah yang berlebihan. Perasaan rendah diri juga bisa terjadi bila apa yang telah dikerjakan anak sebaik-baiknya, dipandang tidak berarti oleh guru dan teman sebayanya. 
Cara mengatasinya: Untuk itu sangat diperlukan pemberian kesempatan penghargaan dn pengakuan dari orang tua maupun guru yang baik agar dapat membantu menstimulasi mendorong potensi yang dimiliki anak agar berkembang dan terbangkitkan semangat/bakatnya yang terpendam.

Masa remaja; Remaja adalah tahap yang kacau, pada saat ini terjadi perubahan psiologis yang dramatis. Dorongan sexual dan agresif mengancam ego dengan defence-defence/pertahanannya. Zone genital ini merupakan saat penanaman energi sexual yang terbesar. Remaja sekali lagi mengalami lamunan oedipal, mengalami kesulitan dengan pengalamannya dan orang tuanya. Jadi peningkatan drive ini mengganggu remaja, dia jadi bingung dengan konflik dan tuntunan sosial yang baru.

Peranan masa kanak-kanak kini tidak sesuai lagi dengan penampilannya yang baru, serta perasaan-perasaannya terhadap lawan jenisnya, juga harapan orangtua, orang dewasa dan teman sebayanya. Kebingungan yang muncul pada awal remaja dinamakan krisis identitas.

Jadi tugas utama remaja adalah membentuk pengertian baru tentang ego identitas, yaitu suatu perasaan untuk mengenal siapa dirinya dan bagaimana penempatan dirinya dalam susunan sosial. Yang menjadi masalah sebenarnya bukan petumbuhan fisiknya atau impuls-impuls sexnya, tetapi pikirannya.

Formasi identitas ini ciri-cirinya dibentuk melalui identifikasi. Dari siapa yang tampil kepada kita dan menjadikan kita menyenangi mereka. Juga melalui prestasi, seperti kemampuan untuk berdiri sendiri, menulis, melukis dan segala sesuatu yang berhubungan dengan ego identitas yang merupakan ciri yang positif dan abadi. Bahaya terbesar pada periode ini adalah role confussion atau krisis identitas. Dimana remaja tidak mengenal siapa dirinya sendiri atau siapa dia bagi orang lain. Karena remaja mengidentifikasikan dirinya secara berlebihan terhadap tokoh-tokoh pahlawannya, sementara mereka kehilangan dirinya sendiri. Mereka seringkali konflik dengan orang tuanya, saudara kandung atau orang yang dekat dengannya.

Konflik atau krisis yang dihadapi adalah identitas lawan role confussion tumbuh kembang sebelum lahir (yang dilakukan oleh alim ulama untuk memperkuat keimanan dalam menjalankan hidup berumah tangga, dokter spesialis kandungan dan BKIA bagi kesehatan psikolog mempersiapkan peran ibu serta stimulasi bagi janin dalam kandungan) dilanjutkan dengan stimulasi tumbuh kembang anak sebelum lahir (dilakukan oleh dokter spesialis anak, dokter spesialis syaraf dan BKIA untuk kesehatannya bekerjasama dengan psikolog, therapis bagi stimulasi tubuh kembang anak mulai usia dini juga alim ulama dalam membentuk akhlaqul karimah) diharapkan dapat membantu mengoptimalkan potensi anak sesuai dengan kemampuan yang dimilikinya. 


\section{Daftar Pustaka}

Hurlock ellizabeth,B.1978. child development. Sixth edition. Mc Graw HILL,ltd kogakusha.

Hall.Calvin,S.\&hardner Lindzey, 1985. Introduction to theories of personality, New York :john Willey and Sons

Syamsu Yusuf, 2005,psikologi perkembangan anak dan remaja,Rosdakarya : Bandung

Soetjiningsih, 1998,Tumbuh kembang anak,lab kesehatan UNAIR,Surabaya. 
Psympathic, 2009, Vol. III, No.1: 120 - 130 